\title{
Evaluation of Cases of Infantile Hemangioma Requiring Treatment
}

\author{
Hüsnü Maraşli ${ }^{1}$, Can Acipayam ${ }^{2}$, Ufuk Utku Güllü̈ ${ }^{3}$, Serpil Dinçer ${ }^{1}$, Emine Füheda Dalgiç ${ }^{4}$, \\ Seda Nida Karaküu̧ük ${ }^{5}$, Sadik Yurttutan ${ }^{6}$ \\ ${ }^{1}$ Department of Pediatrics, Faculty of Medicine, Kahramanmaras Sutcu Imam University, Kahramanmaras, Turkey \\ ${ }^{2}$ Department of Pediatrics, Division of Pediatric Hematology and Oncology, Faculty of Medicine, Kahramanmaras Sutcu Imam University, \\ Kahramanmaras, Turkey \\ ${ }^{3}$ Department of Pediatrics, Division of Cardiology, Faculty of Medicine, Kahramanmaras Sutcu Imam University, Kahramanmaras, Turkey \\ ${ }^{4}$ Department of Pediatric Cardiology, Necip Fazil Maternity and Children Hospital, Kahramamaras, Turkey \\ ${ }^{5}$ Department of Radiology, Faculty of Medicine, Kahramanmaras Sutcu Imam University, Kahramanmaras, Turkey \\ ${ }^{6}$ Department of Pediatrics, Division of Neonatology, Faculty of Medicine, Kahramanmaras Sutcu Imam University, Kahramanmaras, Turkey
}

Corresponding author: Can Acipayam, Department of Pediatrics, Division of Pediatric Hematology and Oncology, Faculty of Medicine, Kahramanmaras Sutcu Imam University, Avsar Campus, Kahramanmaras, 46100, Turkey; E-mail: cacipayam@hotmail.com; Tel.: +90-3443003765

Received: 13 Sep 2020 Accepted: 8 Feb 2021 Published: 28 Feb 2022

Citation: Maraşli H, Acipayam C, Güllü UU, Dinçer S, Dalgiç EF, Karaküçük SN, Yurttutan S. Evaluation of cases with infantile hemangioma requiring treatment. Folia Med (Plovdiv) 2022;64(1):67-74. doi: 10.3897/folmed.64.e58616.

\section{Abstract}

Aim: Infantile hemangiomas are the most common benign vascular tumours in infants. In this study, we aimed to evaluate the effectiveness of propranolol therapy in patients with infantile hemangioma.

Materials and methods: This study included patients with infantile hemangiomas in the age range of 0 to 24 months who received propranolol therapy between September 2015 and 2019. Hemangioma activity score, ultrasonography imaging and photographic evaluations were performed before and at 6 months of treatment. Parental satisfaction with the results of treatment was recorded.

Results: Our study included 85 patients with infantile hemangioma requiring treatment. Twenty patients were boys and 65 were girls. The mean age at starting treatment was 7.2 \pm 5.9 months (median: 5.0). While the average lesion area measured by ultrasonography before treatment was $209.7 \pm 207.5 \mathrm{~mm}^{2}$, it reduced to $105.1 \pm 145.7 \mathrm{~mm}^{2}(p<0.001)$ after treatment. Similarly, while the mean hemangioma activity score was $3.8 \pm 0.9$ before treatment, it decreased significantly to $1.3 \pm 0.8$ after the treatment $(p<0.001)$. A noticeable improvement in photographic evaluation with the treatment was observed in infantile hemangiomas of the patients and $82 \%$ of the families were satisfied with the results of the treatment.

Conclusions: The results of the study suggested that propranolol therapy used in the treatment of infantile hemangioma is an effective treatment option according to the photographic comparison, ultrasonography data, and hemangioma activity score evaluations.

\section{Keywords}

hemangioma, infant, propranolol, treatment, ultrasonography

\section{INTRODUCTION}

Infantile hemangiomas ( $\mathrm{IH})$ are the most common type of vascular tumours in infancy and childhood. ${ }^{1,2}$ Uncomplicated infantile hemangiomas, can be usually observed up to 18 months. Infantile hemangiomas, if not complicated, could regress. Therefore, patients who did not need treatment were followed up without the propranolol treatment. However, infantile hemangiomas should be treated in the setting of bleeding, ulceration, functional dysfunction and 
no regression of the lesion. ${ }^{3}$ Today, propranolol has become the mainstay of the treatment of this condition. ${ }^{4}$

Two scoring systems for infantile hemangiomas have been proposed to help clinicians assess the disease severity and treatment response: 1 . The Hemangioma Severity Scale (HSS) was created in 2012 to divide patients into subgroups according to their complication risk profile and to help guide to their treatment needs. ${ }^{5} ; 2$. Hemangioma activity score (HAS) was developed in 2011 and is largely based on colour profiles of infantile hemangioma lesions. ${ }^{5}$ In the performed studies so far, while determining the effectiveness of propranolol in the treatment, evaluations were also done with ultrasonography (USG) data and photographic evaluations. ${ }^{6,7}$ There is no study in the literature, in which photographic evaluation, HAS score, and USG data were used together in the follow-up of infantile hemangiomas.

\section{AIM}

Our aim in this study was to evaluate objectively the efficiency of propranolol in treating patients with infantile hemangioma who received propranolol treatment by questioning HAS scores, USG data, photographic evaluations and satisfaction of their families.

\section{MATERIALS AND METHODS}

We included in this study patients diagnosed with infantile hemangioma between September 2015 and September 2019 (aged 0-24 months), who started to take propranolol orally and were followed up afterwards. Ethics committee approval (2018/08) was obtained from the local Clinical Research Ethics Committee. The parents of the children included in the study were given detailed information about the study and a written informed consent was obtained from them.

A detailed medical history and demographic information of the patients included in the study were obtained. The hemangioma location, size, and hemangioma type were recorded from the files. USGs were performed to patients as radiological imaging. The patients were evaluated by a cardiologist with physical examination, echocardiography (ECHO) and electrocardiogram before treatment. While initiating propranolol therapy, the patients were hospitalized and monitored to ensure that they were not exposed to the side effects of the drug. Subsequent visits of the patients were done in the outpatient clinic. The drug was started with a low dose of $0.5 \mathrm{mg} / \mathrm{kg} /$ per day for two days and reached up to $2 \mathrm{mg} / \mathrm{kg} /$ day. Blood pressure, pulse, respiration, and blood sugar were monitored during the hospital stay. The patients were invited to weekly controls within the first month after starting the propranolol treatment and monthly controls after the first month. Hemangioma dimensions of the patients were measured regularly every month with USG and photographic evaluation. Photographs of the patients before treatment and at 6 months of treatment were evaluated according to the scoring used in a study performed by Janmohamed et al. ${ }^{8}$ and the patients' scores were recorded as response to the treatment (Table 1).

Table 1. Haemangioma Activity Score Form ${ }^{8}$

\begin{tabular}{ll}
\hline Criteria Title & Score \\
\hline Swelling score & \\
Deep swelling: tense haemangioma & 6 point \\
'Neutral' or $<50 \%$ reduction at follow-up & 4 point \\
$\geq 50 \%$ reduction at follow-up & 2 point \\
No more swelling at follow-up & 0 point \\
Colour & \\
Bright/shining red all over [5] OR bright- & 5 point $/ 4$ point \\
red edge [4] & \\
Red or red-purple OR matt red edge & 3 point \\
Blue (or blue background in deep heman- & 2 point \\
giomas) & 1 point \\
Grey & 0 point \\
Skin-coloured after activity & \\
Total & \\
Number of items scored & \\
Preliminary HAS=total $\div$ number of items & \\
scored & \\
Ulceration & \\
Ulcer $\leq 1 \mathrm{~cm}^{2}$ & 0.5 point \\
Ulcer $1-25 \mathrm{~cm}^{2}$ & \\
Ulcer $\geq 25 \mathrm{~cm}^{2}$ & point \\
HAS=preliminary HAS + ulcer score & \\
\hline
\end{tabular}

\section{Statistical analysis}

Statistical analysis was performed using SPSS 22.0 for Windows (SPSS, Inc.; Chicago, USA) package program. Descriptive values are stated as number (n), percentage (\%), mean (avg.), and Standard deviation (SD), median (median). Pearson chi-square and Fisher tests were used to compare categorical variables. The conformity of the data to normal distribution was tested with the Kolmogorov-Smirnov and Shapiro-Wilk tests. Continuous variables were compared with parametric tests (paired sample $t$ test and $t$ test in independent groups) where it fits normally, and nonparametric tests (Wilcoxon, Mann-Whitney U, and Kruskal-Wallis test) where it does not comply with normal distribution. Significance level was taken as $p<0.05$.

\section{RESULTS}

Between September 2015 and September 2019, a total of 236 patients applied to our clinic with the diagnosis of 
hemangioma. Eighty-five of these patients were included in the study. Similar to the relevant literature, the following points were taken into consideration when the patients were included in the treatment: cases with infantile hemangioma posing cosmetic problems, ulcerated, bleeding, large size, respiratory distress and intention to require surgery if left untreated were treated. ${ }^{3}$ Twenty patients were male $(23.5 \%)$ and 65 were female $(76.5 \%)$ (Table 2$)$. The birth week of the patients included in the study was $37.5 \pm 2.2$ weeks (Table 3). Five patients (5.9\%) were delivered early preterm, 8 patients $(9.4 \%)$ were late preterm, and 72 patients $(84.7 \%)$ were born in term. Two patients $(2.4 \%)$ were born under $1500 \mathrm{~g}, 15$ patients (17.6\%) weighed 1500 $2500 \mathrm{~g}$ and 68 patients $(80.0 \%)-2500 \mathrm{~g}$ and above. While $76.5 \%$ of hemangiomas were single, $23.5 \%$ were multiple, and the most common areas were head-neck with $42.4 \%$ and extremity-body with $34.1 \%$, respectively (Table 4). Only 2 patients $(2.4 \%)$ had visceral involvement and this involvement was in the liver. Looking at the locations of hemangiomas in the body, single hemangiomas are seen in $43.1 \%$ head-neck, $33.8 \%$ extremity-body, $12.3 \%$ anogenital region; multiple hemangiomas were seen in $40.0 \%$ headneck, $35.0 \%$ extremity-body, $10.0 \%$ internal organs. There was no statistically significant difference between hemangioma being single or multiple and their location $(p=0.063)$. When the distribution of hemangiomas on the skin was examined, it was observed that $42.4 \%$ were superficial, $22.4 \%$ were deep and $35.3 \%$ - mixed. While $49.4 \%$ of the patients had no complications related to hemangioma, $32.9 \%$ of them had cosmetic problems, 5.9\% had ulceration, 5.9\% had bleeding and 5.9\% had other complications (Table 5).

Table 2. Gender and parent kinship status in the cases

\begin{tabular}{lll}
\hline & $\mathbf{n}$ & \% \\
\hline Gender & & \\
Male & 20 & 23.5 \\
Female & 65 & 76.5 \\
Kinship & & \\
Yes & 12 & 14.1 \\
No & 73 & 85.9 \\
\hline
\end{tabular}

$\mathrm{n}$ : frequency
Consumptive hypothyroidism was observed in hepatic and parotid infantile hemangiomas in previous studies. ${ }^{9}$ Therefore, we checked thyroid function tests (TSH and FT4) in all patients with infantile hemangioma before the propranolol treatment. In the examination results, there were 6 patients $(7.1 \%)$ who were accepted to have hypothyroidism with Free T4 (FT4 0.8-1.9 ng/dL) and TSH (TSH: 0.27-4.2 $\mathrm{mIU} / \mathrm{L}$ ) values outside the reference range. The propranolol dose given in the treatment of the patients was determined by the recommendation of the pediatric cardiologist after evaluation with ECHO. Propranolol was given to $18.8 \%$ of the patients at a dose of $1 \mathrm{mg} / \mathrm{kg} /$ day and to $81.2 \%$ at a dose of $2 \mathrm{mg} / \mathrm{kg} /$ day. Mean age to start treatment was 7.2 \pm 5.9 months (median 5 months, range 0-24 months). Mean propranolol discontinuation time was $8.3 \pm 4.6$ (median 8 months). We could not achieve the desired result in our 15 patients on propranolol treatment. Side effects of medication and discontinuation of the treatment were considered as the reason for the failure. Propranolol-related complications were observed in 4 patients (4.7\%); respiratory distress in 2 patients, hypoglycemia in 1 patient, and hypotension in 1 patient. In 4 of our patients, treatment was discontinued due to drug complications. The patients we call non-follow-up are those who do not apply to our clinic after starting treatment due to the reasons we do not know, or who come to our clinic irregularly and cannot be followed up regularly. Approximately $3.5 \%$ of the patients did not come to follow-up, and $14.1 \%$ of them were followed up at irregular intervals. Therefore, USG and photographic evaluations of these patients could not be done completely. Sonographic lesion size was measured in 75 (78.8\%) of the cases included in the study and photographic evaluation was performed in $70(82.4 \%)$ cases. The lesion area and the change of HAS score in the USG were examined before and after the treatment. USG area before the propranolol treatment of infantile hemangiomas was $209.7 \pm 207.5 \mathrm{~mm}^{2}$, it decreased to $105.1 \pm 145.7 \mathrm{~mm}^{2}$ after treatment which was a statistically significant reduction $(p<0.001)$ (Table 6). Similarly, while the mean HAS score was $3.8 \pm 0.9$ before the treatment, it decreased to $1.3 \pm 0.8$ after treatment which was statistically significant $(p<0.001)$ (Table 6). Significant improvement was also observed in the photographic evaluations of the patients (Figs 1-3). In general, the families of

Table 3. Descriptive information regarding age, birth week, body weight, height, and head circumference of the cases

\begin{tabular}{llllll}
\hline & Unit & $\mathbf{n}$ & Mean \pm SS & Median & Minimum-Maximum \\
\hline Age & month & 85 & $7.2 \pm 5.9$ & 5.0 & $0-24$ \\
Birth week & week & 85 & $37.5 \pm 2.2$ & 38.0 & $29-41$ \\
Birth weight & $\mathrm{g}$ & 85 & $3039.2 \pm 749.0$ & 3100.0 & $745-4700$ \\
Body weight & $\mathrm{g}$ & 85 & $7469.2 \pm 2195.9$ & 7000.0 & $955-14000$ \\
Height & $\mathrm{cm}$ & 85 & $66.7 \pm 9.6$ & 66.0 & $33-95$ \\
$\begin{array}{l}\text { Head circumfer- } \\
\text { ence }\end{array}$ & $\mathrm{cm}$ & 85 & $42.2 \pm 4.0$ & 42.0 & $23.5-49.0$ \\
\hline
\end{tabular}

n: frequency; SS: standard deviation 
Table 4. Number of hemangiomas and their involvement locations

\begin{tabular}{lll}
\hline & $\mathbf{n}$ & \% \\
\hline A single hemangioma & 65 & 76.5 \\
Multiple hemangioma & 20 & 23.5 \\
Head-neck & 36 & 42.4 \\
Extremity-body & 29 & 34.1 \\
Periocular & 8 & 9.4 \\
Anogenital & 8 & 9.4 \\
Internal organ & 2 & 2.4 \\
Inside mouth & 2 & 2.4 \\
Total & 85 & 100.0 \\
\hline
\end{tabular}

$\mathrm{n}$ : frequency; $\%$ : column percentage
Table 5. Distribution of hemangioma complications

\begin{tabular}{lll}
\hline & $\mathbf{n}$ & \% \\
\hline There are no complications & 42 & 49.4 \\
Cosmetic problem & 28 & 32.9 \\
Ulceration & 5 & 5.9 \\
Bleeding & 5 & 5.9 \\
Ulceration + bleeding + cosmetic & 2 & 2.4 \\
problems & 1 & 1.2 \\
Airway obstruction & 1 & 1.2 \\
Bleeding + cosmetic problems & 1 & 1.2 \\
$\begin{array}{l}\text { Mortality secondary to Kasabach } \\
\text { Merritt syndrome }\end{array}$ & 1 & 100.0 \\
Total & 85 & \\
\hline
\end{tabular}

$\mathrm{n}$ : frequency

Table 6. Comparison of patients with USG and HAS score before and after propranolol treatment

\begin{tabular}{llllll}
\hline & $\mathbf{n}$ & Mean \pm SD & Median & Minimum-Maximum & $\boldsymbol{p}^{*}$ \\
\hline Receiving USG before treatment & 75 & $209.7 \pm 207.5$ & 126.0 & $3.0-1250.0$ & $<\mathbf{0 . 0 0 1}$ \\
Receiving USG after treatment & 75 & $105.1 \pm 145.7$ & 41.0 & $0.0-640.0$ & $<0.001$ \\
HAS score before treatment & 70 & $3.8 \pm 0.9$ & 4.0 & $2.0-6.0$ & $<.0-4.0$ \\
HAS score after treatment & 70 & $1.3 \pm 0.8$ & 1.3 & $<$ \\
\hline
\end{tabular}

HAS: haemangioma activity score; ${ }^{*}$ Wilcoxon test
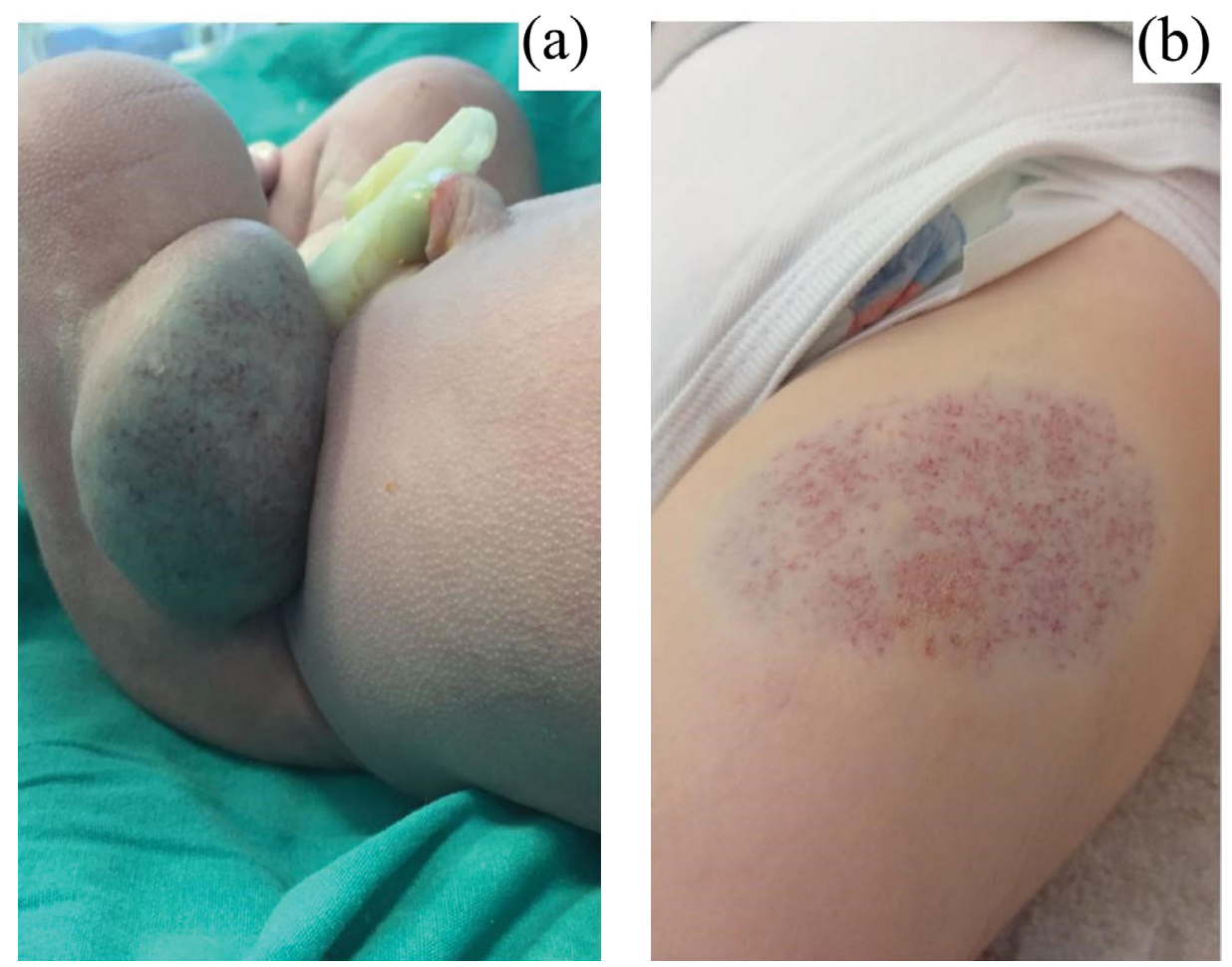

Figure 1. Example of infantile hemangioma before and after treatment. (a) a hemangioma on the left leg before treatment; (b) a hemangioma on the left leg after treatment. 

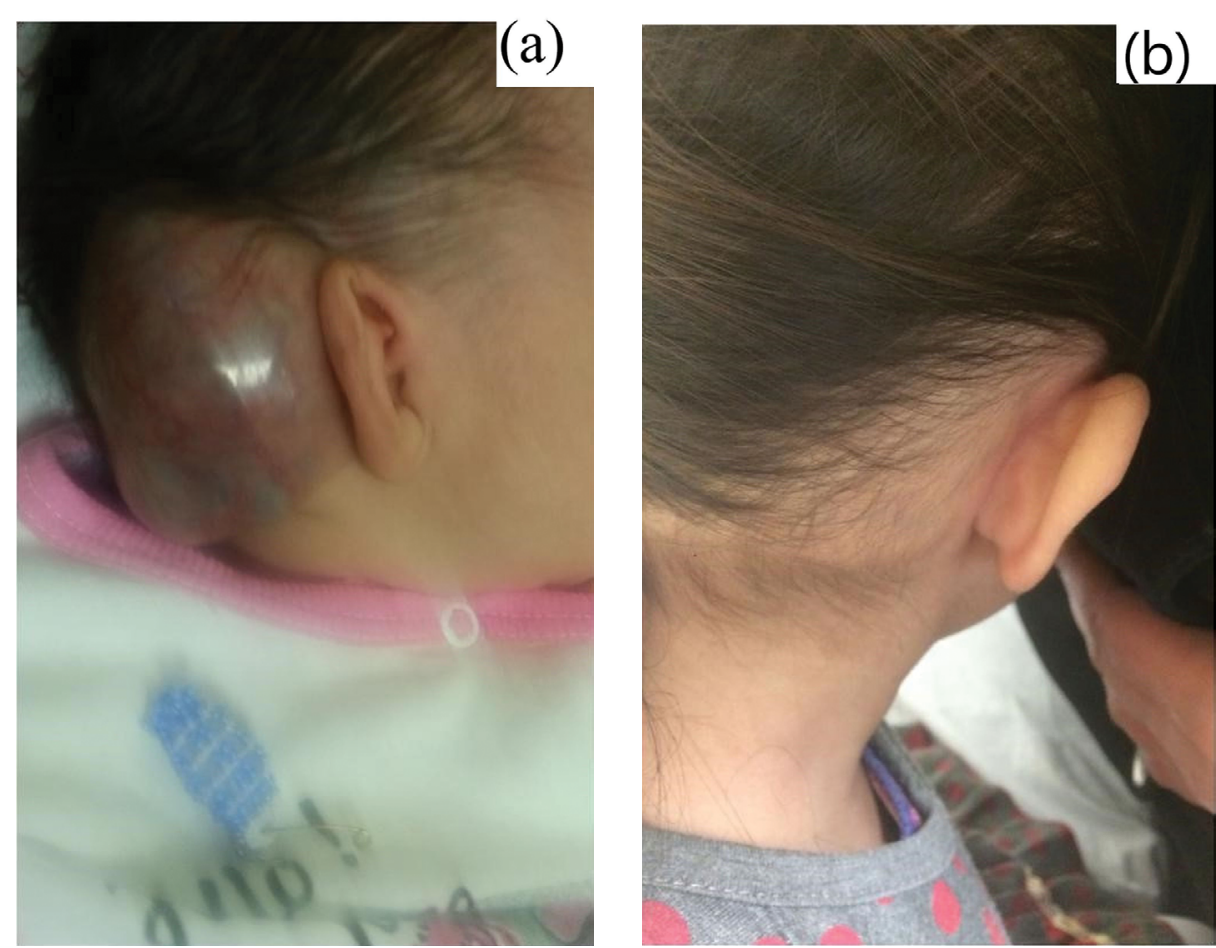

Figure 2. Example of infantile hemangioma before and after treatment. (a) a large hemangioma in the right post auricular area before treatment; (b) a hemangioma in the right post auricular area after treatment.
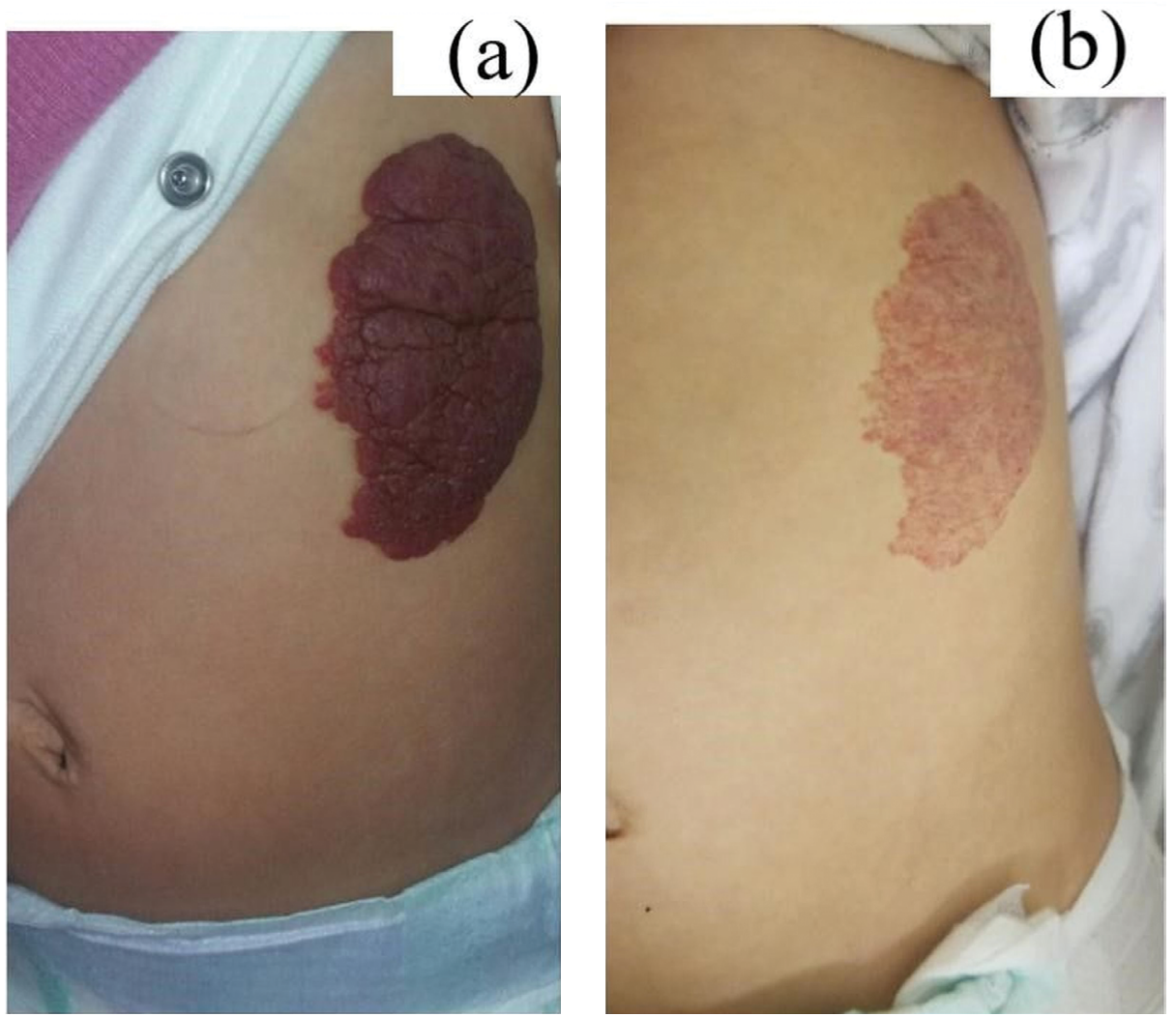

Figure 3. Example of infantile hemangioma before and after treatment. (a) a hemangioma in the left chest area before treatment; (b) a hemangioma in the left chest area after treatment. 
the patients $(82 \%)$ who regularly attended to the treatment follow-up stated that the propranolol treatment was beneficial in the regression of infantile hemangioma. No information was obtained or negative reports were received from the families (18\%) who had irregular or no follow-up visits.

\section{DISCUSSION}

Although infantile hemangiomas usually enter the process of involution spontaneously, it is necessary to closely monitor the natural course of these benign lesions. It should be taken into consideration that infantile hemangiomas can progress and, accordingly, have undesirable results and the necessity of early treatment should be evaluated very well. ${ }^{10}$ It has been stated in the literature that propranolol is effective in the treatment of infantile hemangioma. ${ }^{11}$ In our study, it was shown that the propranolol therapy applied in indicated cases such as infantile hemangiomas being large in size, causing bleeding and ulceration, airway obstruction and cosmetic problems was effective.

In this study, 85 patients were evaluated over a 4 -year period. Similar to the study conducted by Ding et al. ${ }^{12}$, infantile hemangioma was observed more frequently in females in our study. Boo et al. ${ }^{13}$ found that low birth weight was a risk factor for $\mathrm{IH}$, while for Ding et al. ${ }^{12}$ it was also the low gestation week. In our study, contrary to these studies, patients born in term and birth weight over $2500 \mathrm{~g}$ were more frequent. Similar to the study conducted by Düzenli Kar et al. ${ }^{14}$, cosmetic problems were observed more frequently in our study too. Oliveira et al. ${ }^{15}$ emphasized that the presence of hemangioma should not be ignored in the patients with stridor. In our study, airway obstruction was observed in one patient who presented with stridor. Mortality secondary to Kasabach-Merritt Syndrome was observed in one of our patients. In our study, hypothyroidism was detected in 6 of 85 patients as a result of thyroid function tests that were examined before the propranolol treatment. In our study, as consistent with the literature, propranolol treatment was found to be effective for infantile hemangiomas. ${ }^{6,11,14}$ In the literature, propranolol has been used ( $2 \mathrm{mg} / \mathrm{kg} /$ day) as two divided doses in the treatment of infantile hemangioma. ${ }^{16}$ We used the propranolol in accordance with the literature. Zhang et al. ${ }^{17}$ mentioned sleep disorders, diarrhea, and bronchospasm among the side effects of propranolol in the treatment of infantile hemangioma. However, in our study, respiratory distress, hypoglycemia and hypotension were among the observed side effects.

The HAS that we used in our study and the HSS reported by Moyakine et al. ${ }^{18}$ are the scores used to evaluate the treatment of infantile hemangiomas. Haggstrom et al. ${ }^{19}$ state that the HSS is important in evaluating the clinical results of infantile hemangioma. In a study, it was reported that the propranolol treatment was effective in patients with infantile hemangioma using HAS scoring. ${ }^{20}$ The authors think the HAS is more suitable to use in photographs. Janmohamed et al. ${ }^{21}$ concluded in their study that the HAS was preferred to the HSS in evaluating the response of infantile hemangioma to this treatment. Mull et al. ${ }^{22}$ and Moyakine et al. ${ }^{23}$ reported that the HSS may contribute to making treatment decisions in the patients with infantile hemangioma. In the light of the data in the literature, we used the HAS scoring in our study to evaluate our patients' response to propranolol therapy. In some studies, besides scoring such as HAS and HSS, photographic evaluation was used to evaluate the response to the treatment, whereas in other studies, evaluation was performed with USG. In the studies conducted by Jamshidian-Tehrani et al. ${ }^{7}$ and Al-Mahdi et al. ${ }^{24}$, the evaluation of the cases with infantile hemangioma was performed with USG. Jamshidian-Tehrani et al. ${ }^{7}$ showed that USG and color Doppler imaging were useful methods for monitoring and evaluating the treatment response. In our study, follow-up of the patients was performed by exploring USG evaluations before, during, and after the treatment. In the study conducted by Ainipully et al. ${ }^{11}$, the effectiveness of propranolol in infantile hemangioma was investigated by interpreting the photographs taken in the follow-up of the patients with infantile hemangioma with visual analog scale, measuring hemangioma dimensions in length and width and evaluating the satisfaction of the parents. In the study of Kridin et $\mathrm{al}^{25}$ in the clinical evaluation of the patients receiving oral propranolol, the photographs of each case taken at the controls were evaluated using a visual analog scale. And also in the study of Kim et al. ${ }^{6}$, the photographic evaluations were done in the controls of the patients with infantile hemangioma who received the propranolol treatment. In our study, each patient's photographic evaluations were made before, during, and after treatment, and a significant improvement was observed in infantile hemangiomas with the propranolol treatment. Approximately $82 \%$ of patients' families stated that the propranolol treatment visibly reduced the size of IH and dimmed its colour.

In our study, while evaluating the response to the propranolol treatment, the HAS scoring, USG data, and photographic evaluation were taken as criteria. Familial' satisfaction was questioned at every check. Considering other studies in the literature, we believe that our study is more objective, since the HAS score, the USG data, and photographic evaluation were used together to evaluate the response to the treatment.

\section{CONCLUSIONS}

To our knowledge this is the first study in which the HAS score, the USG data, and photographic evaluation parameters were used together. As a result of all these evaluations, the propranolol treatment in our study was found to be an effective and reliable treatment modality in infantile hemangiomas. 


\section{Acknowledgements}

We would like to thank all our patients with infantile hemangioma, their families, and our clinic staffs for supporting the study.

\section{Author contributions}

H.M. and C.A. designed the study; U.U.G., S.N.K., and E.F.D. collected and analyzed data; S.D. and S.Y. wrote the manuscript. All authors read and approved the final manuscript.

\section{Disclosure}

The authors declare no conflict of interest.

\section{REFERENCES}

1. Krowchuk DP, Frieden IJ, Mancini AJ, et al. Clinical practice guideline for the management of infantile hemangiomas. Pediatrics 2019;143(1).

2. Chen ZY, Wang QN, Zhu YH, et al. Progress in the treatment of infantile hemangioma. Ann Transl Med 2019; 7(22):692.

3. Soliman YS, Khachemoune A. Infantile hemangiomas: our current understanding and treatment options. Dermatol Online J 2018;24(9)

4. Langley A, Pope E. Propranolol and central nervous system function: potential implications for paediatric patients with infantile haemangiomas. Br J Dermatol 2015; 172(1):13-23.

5. Satterfield KR, Chambers CB. Current treatment and management of infantile hemangiomas. Surv Ophthalmol 2019; 64(5):608-18.

6. Kim J, Hong JW, Roh TS, et al. Oral propranolol therapy in 23 infants with infantile hemangioma. Arch Plast Surg 2018; 45(6):517-24.

7. Jamshidian-Tehrani M, Nabavi A, Taghavi M, et al. Clinical and ultrasonographic evaluation of infantile periocular hemangioma treated with oral propranolol. Ophthalmic Plast Reconstr Surg 2019; 35(5):484-6.

8. Janmohamed SR, de Waard-van der Spek FB, Madern GC, et al. Scoring the proliferative activity of haemangioma of infancy: the Haemangioma Activity Score (HAS). Clin Exp Dermatol 2011; 36(7):715-23.

9. De Corti F, Crivellaro C, Zanon GF, et al. Consumptive hypothyroidism associated with parotid infantile hemangioma. J Pediatr Endocrinol Metab 2015; 28(3-4):467-9.

10. Chang SJ, Qiao C, Chang L, et al. A 7-year follow-up study on un- treated deep or mixed facial infantile hemangioma in East-Asian patients: when propranolol was not yet an option. J Dermatol 2019; 46(11):962-6.

11. Ainipully AM, Narayanan SK, Vazhiyodan AP, et al. Oral propranolol in infantile hemangiomas: analysis of factors that affect the outcome. J Indian Assoc Pediatr Surg 2019; 24(3):170-5.

12. Ding Y, Zhang J-Z, Yu S-R, et al. Risk factors for infantile hemangioma: a meta-analysis. World J Pediatr 2020; 16(4):377-84.

13. Boo NY, Lim SM, Koh KT, et al. Risk factors associated with low birth weight infants in the Malaysian population. Med J Malaysia 2008; 63(4):306-10.

14. Duzenli Kar Y, Ozdemir ZC, Acu B, et al. Infantile hemangioma: efficacy of low-dose propranolol and of intralesional bleomycin injection for propranolol non-response. Pediatr Int 2019; 61(5):459-64.

15. Oliveira JC, Azevedo I, Goncalves A, et al. Stridor is not always croup: infantile haemangioma in the airway. BMJ Case Rep 2017; 2017: bcr-2017.

16. Babiak-Choroszczak L, Gizewska-Kacprzak K, Dawid G, et al. Safety assessment during initiation and maintenance of propranolol therapy for infantile hemangiomas. Adv Clin Exp Med 2019; 28(3):375-84.

17. Zhang L, Wu HW, Yuan W, et al. Propranolol therapy for infantile hemangioma: our experience. Drug Des Devel Ther 2017; 11:1401-8.

18. Moyakine AV, Spillekom-van Koulil S, Kupers EM, et al. Influence of infantile hemangioma severity and activity on QoL of patients and their parents: A cross-sectional study. Pediatr Dermatol 2018; 35(5):628-34.

19. Haggstrom AN, Beaumont JL, Lai JS, et al. Measuring the severity of infantile hemangiomas: instrument development and reliability. Arch Dermatol 2012; 148(2):197-202.

20. Livani F, Layegh P, Alizadeh B, et al. Propranolol for infantile hemangioma: An evaluation of its efficacy and safety in Iranian infants. Iran J Neonatol 2016; 7(3):17-20.

21. Janmohamed SR, van Oosterhout M, de Laat PC, et al. Scoring the therapeutic effects of oral propranolol for infantile hemangioma: a prospective study comparing the Hemangioma Activity Score (HAS) with the Hemangioma Severity Scale (HSS). J Am Acad Dermatol 2015; 73(2):258-63

22. Mull JL, Chamlin SL, Lai JS, et al. Utility of the hemangioma severity scale as a triage tool and predictor of need for treatment. Pediatr Dermatol 2017; 34(1):78-83.

23. Moyakine AV, Herwegen B, van der Vleuten CJM. Use of the hemangioma severity scale to facilitate treatment decisions for infantile hemangiomas. J Am Acad Dermatol 2017; 77(5):868-73.

24. Al-Mahdi AH, Al-Sada MA. Assessment of oral propranolol administration for infantile hemangioma in oral and maxillofacial region aided by ultrasonography. J Craniofac Surg 2020; 31(1):189-92.

25. Kridin K, Pam N, Bergman R, et al. Oral propranolol administration is effective for infantile hemangioma in late infancy: A retrospective cohort study. Dermatol Ther 2020:e13331. 


\title{
Оценка случаев детской гемангиомы, требующих лечения
}

\author{
Хюсню Марашли ${ }^{1}$, Джан Аджипаям², Уфук Утку Гюллю ${ }^{3}$, Серпил Динчер ${ }^{1}$, \\ Емине Фюхеда Далджич ${ }^{4}$, Седа Нида Каракючюк ${ }^{5}$ Садик Юртутан ${ }^{6}$ \\ ${ }^{1}$ Кафедра педиатрии, Медицинский факультет, Университет имени Кахраманмараша Сютчуйама, Кахраманмараш, Туриия \\ ${ }^{2}$ Кафедра педиатрии, Отделение детской гематологии и онкологии, Медииинский факультет, университет имени Кахраманмараша \\ Сютчуйама, Кахраманмараш, Туриия \\ ${ }^{3}$ Кафедра педиатрии, Отделение кардиологии, Медииинский факультет, Университет имени Кахраманмараша Сютчуйама, \\ Кахраманмараш, Туриия \\ ${ }^{4}$ Кабедра детской кардиологии, Родильньй дом и педиатрическая больнииа „Неджип Фазыл“, Кахраманмараш, Туриия \\ ${ }^{5}$ Кафедра радиологии, Медииинский факультет, Университет имени Кахраманмараша Сютчуйама, Кахраманмараш, Туриия \\ ${ }^{6}$ Кафедра педиатрии, Отделение неонатологии, Медицинский факультет, Университет имени Кахраманмараша Сютчуйама, \\ Кахраманмараш, Туриия
}

Адрес для корреспонденции: Джан Аджипаям, Кафедра педиатрии, Отделение детской гематологии и онкологии, Медицинский факультет, Университет имени Кахраманмараша Сютчуйама, Кампус „Авсар“, 46100, Кахраманмараш, Турция; E-mail: cacipayam@hotmail.com; Тел.: $+90-3443003765$

Дата получения: 13 сентября 2020 Дата приемки: 8 февраля 2021 Дата публикации: 28 февраля 2022

Образец цитирования: Maraşli H, Acipayam C, Güllü UU, Dinçer S, Dalgiç EF, Karaküçük SN, Yurttutan SY. Evaluation of cases with infantile hemangioma requiring treatment. Folia Med (Plovdiv) 2022;64(1):67-74. doi: 10.3897/folmed.64.e58616.

\section{Резюме}

Цель: Детские гемангиомы являются наиболее распространёнными доброкачественными сосудистыми опухолями у детей. В этом исследовании нашей целью было оценить эффективность терапии пропранололом у детей с гемангиомами.

Материалы и методы: В это исследование были включены пациенты с гемангиомами среди детей в возрасте от 0 до 24 месяцев, получавшие лечение пропранололом в период с сентября 2015 по 2019 год. Исследования активности гемангиом, ультразвуковое исследование и фотографические оценки проводились до и на 6-м месяце лечения. Сообщается об удовлетворённости родителей результатами лечения.

Результаты: В наше исследование были включены 85 пациентов с гемангиомами среди детей, нуждающихся в лечении. 20 пациентов были мальчиками и 65 девочками. Средний возраст на исходном уровне составлял $7.2 \pm 5.9$ месяца (в среднем: 5.0). В то время как средняя площадь поражения, измеренная с помощью УЗИ до лечения, составляла $209.7 \pm 207.5$ мм², после лечения она уменьшилась до $105.1 \pm 145.7$ мм² $^{2}(p<0.001)$. Точно так же, хотя средний балл активности гемангиомы составлял 3.8 \pm 0.9 до лечения, он значительно снизился до $1.3 \pm 0.8$ после лечения $(p<0.001)$. Заметное улучшение по фотооценке лечения наблюдалось в детских гемангиомах пациентов и $82 \%$ семей были удовлетворены результатами лечения.

Заключение: Результаты исследования показали, что терапия пропранололом, используемая для лечения гемангиом у детей, была эффективным вариантом лечения на основе сравнения фотографий, данных УЗИ и оценки активности гемангиомы.

\section{Ключевые слова}

гемангиома, младенец, пропранолол, лечение, УЗИ 